ISSN 0103-9954

\title{
ORIGEM DE BROTAÇÕES EPICÓRMICAS E APLICAÇÃO DE ÁCIDO INDOLILBUTÍRICO NO ENRAIZAMENTO DE ESTACAS DE Vochysia bifalcata Warm.
}

\author{
ORIGIN OF EPICORMIC SPROUTS AND USE OF INDOLEBUTYRIC ACID IN ROOTING OF \\ Vochysia bifalcata Warm.
}

\author{
Helena Cristina Ricklii ; Cleusa Bona ${ }^{2}$; Ivar Wendling ${ }^{3}$; Henrique Soares Koehler ${ }^{4}$; Katia Christina \\ Zuffellato-Ribas ${ }^{5}$
}

\begin{abstract}
RESUMO
A guaricica (Vochysia bifalcata) é uma espécie nativa da região litorânea do Estado do Paraná, Santa Catarina, São Paulo, Rio de Janeiro e Minas Gerais, com grande importância ecológica, devido à sua capacidade para regenerar áreas degradadas. No entanto, existem poucas informações sobre a sua propagação, seja sexuada ou assexuada. Uma das causas do baixo enraizamento adventício de estacas caulinares é a maturação dos tecidos coletados para tal fim. Desta forma, o presente trabalho objetivou avaliar diferentes origens de brotações epicórmicas associadas à aplicação de ácido indolilbutírico (AIB) na propagação vegetativa de estacas semilenhosas de Vochysia bifalcata. Foram utilizados dois tipos de estacas (provenientes de brotação de decepa e envergadura de caule) nas quais foram aplicadas duas concentrações de AIB $\left(0\right.$ e $\left.1000 \mathrm{mg} \mathrm{L}^{-1}\right)$. Após o plantio em tubetes com vermiculita de granulometria média e casca de arroz carbonizada, as estacas foram mantidas em casa de vegetação climatizada por 60 dias. Análises anatômicas da base de cada tipo de estaca demonstraram que a presença de fibras na região cortical do caule de estacas de decepa não constituiu uma barreira anatômica para a emissão radicial, pois estas apresentaram maior capacidade de enraizamento $(81 \%)$, maior número de raízes por estaca $(8,0)$ e maior comprimento das raízes $(2,0 \mathrm{~cm})$ em relação àquelas de envergadura de caule, que apresentaram resultados inferiores como porcentagem de enraizamento $(31 \%)$, número de raízes por estaca $(3,3)$ e comprimento das raízes $(0,7 \mathrm{~cm})$. Conclui-se, assim, que o uso de brotações epicórmicas induzidas por decepa de caule proporciona melhor enraizamento adventício do que de envergadura de caule, não necessitando da aplicação de AIB como indutor do enraizamento neste tipo de material.
\end{abstract}

Palavras-chave: Vochysiaceae; estaquia; rejuvenescimento; auxina.

\section{ABSTRACT}

Guaricica (Vochysia bifalcata) is a native species of the coastal region of Paraná, Santa Catarina, São Paulo, Rio de Janeiro and Minas Gerais states, with great ecological importance due its ability to regenerate

1 Bióloga, Doutoranda em Agronomia pela Universidade Federal do Paraná, Setor de Ciências Agrárias, Departamento de Fitotecnia e Fitossanitarismo, Rua dos Funcionários, 1540, Bairro Juvevê, CEP 80035-050, Curitiba (PR), Brasil. crisnenah@gmail.com

2 Bióloga, Dra ${ }^{\mathrm{a}}$, Professora do Departamento de Botânica, Setor de Ciências Biológicas, Universidade Federal do Paraná, Av. Cel. Francisco H. dos Santos , 210, Jardim das Américas, CEP 81531-970, Curitiba (PR), Brasil. cleusabona@ufpr.br

3 Engenheiro Florestal, Dr., Pesquisador da Empresa Brasileira de Pesquisa Agropecuária, Centro Nacional de Pesquisa de Florestas, Estrada da Ribeira, km 111, Jardim Cristina, CEP 83411-000, Colombo (PR), Brasil. ivar.wendling@embrapa.br

4 Engenheiro Florestal, Dr., Professor do Departamento de Fitotecnia e Fitossanitarismo, Setor de Ciências Agrárias, Universidade Federal do Paraná, Rua dos Funcionários, 1540, Bairro Juvevê, CEP 80035-050, Curitiba (PR), Brasil.koehler@ufpr.br

5 Bióloga, Drª., Professora do Departamento de Botânica, Setor de Ciências Biológicas, Universidade Federal do Paraná, Av. Cel. Francisco H. dos Santos , 210, Jardim das Américas, CEP 81531-970, Curitiba (PR), Brasil. kazu@ufpr.br

Recebido para publicação em 3/07/2012 e aceito em 26/09/2013 
degraded areas. However, little information exists about its ability to sexual or asexual propagation. One of the causes of cuttings low rooting is the maturation of collected tissues. Thus, this study aimed to evaluate different epicormic sprout sources (from stump and from bend of stem) and the application of indolebutyric acid (IBA) in rooting cuttings of Vochysia bifalcata. Two types of cuttings were used (of stump and of bend of stem) and were treated with two concentrations of IBA (0 and $\left.1000 \mathrm{mg} \mathrm{L}^{-1}\right)$, and later, the cuttings were kept in a greenhouse for 60 days. Anatomical analysis of the base on each type of cuttings demonstrated that the presence of fibers in the cortical region of the stem cuttings of stump did not constitute an anatomical barrier to issue adventitious roots, because they had higher rooting capacity $(81 \%)$, a higher number of roots per cuttings $(8,0)$ and increased root length $(2,0 \mathrm{~cm})$ compared to those of bend of stem, that showed poorer results as lower rooting percentage $(31 \%)$, lower number of roots per cutting $(3,3)$ and lower root length $(0,7 \mathrm{~cm})$. It is concluded that the use of basal shoots obtained by regrowth of stump provides better rooting than the bend of stem, not requiring the application of IBA as rooting induction treatment for this type of material.

Keywords: Vochysiaceae; cutting; rejuvenation; auxin.

\section{INTRODUÇÃO}

Vochysia bifalcata Warm. - Vochysiaceae, conhecida popularmente como guaricica, pau-devinho, pau-amarelo e murici-vermelho, é uma árvore nativa da Floresta Ombrófila Densa, nos Estados do Paraná, Santa Catarina, São Paulo, Rio de Janeiro e Minas Gerais (LORENZI, 1998; NEGRELLE et al., 2007). É uma espécie secundária inicial com grande importância nas florestas secundárias onde se instala formando agrupamentos densos na fase de capoeira, sendo dominante até a fase de capoeirão, recomendada para processos de regeneração de ecossistemas degradados e em sistemas silviculturais (CARVALHO, 2008).

Por apresentar baixa produção de sementes, dificuldades na obtenção de sementes, com atraso no crescimento e altas taxas de mortalidade das mudas, além do desconhecimento de técnicas em viveiro e uma crescente demanda por mudas, a produção de mudas de Vochysia bifalcata é de difícil realização (CARPANEZZI; CARPANEZZI, 2006; CARVALHO, 2008) tornando a propagação vegetativa via estaquia uma alternativa à propagação da espécie.

Em razão da necessidade cada vez crescente de mudas de espécies florestais nativas e da dificuldade de algumas delas relacionadas à propagação via sementes, uma série de trabalhos vêm sendo desenvolvidos no intuito de otimizar a propagação assexuada pela técnica da estaquia caulinar. Por meio da estaquia é possível garantir a multiplicação de genótipos superiores, além da maior produção de mudas em um menor espaço de tempo. Porém, a capacidade de enraizamento depende do material a ser propagado, na qual a idade ontogenética é determinante para o enraizamento de propágulos vegetativos (WENDLING; XAVIER, 2001; HARTMANN et al., 2011), influenciando negativamente o processo de formação de raízes adventícias, principalmente, em espécies lenhosas.

$\mathrm{O}$ sucesso do enraizamento se deve ao fato de que estacas retiradas de plantas em estádio juvenil de crescimento apresentam maior aptidão a formar raízes do que aquelas retiradas de plantas adultas, pois apresentam substâncias endógenas que promovem a indução e desenvolvimento de raízes adventícias, menor quantidade de inibidores do enraizamento, como também menor lignificação dos tecidos(FACHINELLOetal., 1994; HARTMANN et al., 2011). Propágulos juvenis de plantas adultas são importantes para viabilizar a propagação vegetativa de espécies de difícil enraizamento, uma vez que, quando ramos adultos não enraízam ou enraízam com baixo percentual e pequeno vigor de raízes, como ocorre com a Vochysia bifalcata (DANNER et al., 2010), o rejuvenescimento pode ser uma alternativa viável a ser adotada. Diversas práticas são adotadas para promover o rejuvenescimento dos tecidos e/ou a indução de brotações juvenis em plantas adultas, como estaquia ou enxertia seriada, miniestaquia, micropropagação, poda drástica, curvamento, ou ainda, anelamento (WENDLING; XAVIER, 2001; BITENCOURT, 2009; FERRIANI et al., 2010; HARTMANN et al., 2011). Por meio dessas técnicas, ocorre o resgate das características juvenis do material adulto pela indução do crescimento de brotações epicórmicas, que são brotações juvenis originadas a partir de gemas axilares latentes, denominadas gemas epicórmicas, 
com a finalidade de recompor a copa da planta (SEITZ, 1996). Por meio do rejuvenescimento se obtém um material juvenil com maior capacidade de enraizar, no qual as rebrotas das árvores podem ser utilizadas com sucesso na propagação vegetativa (BORGES JÚNIOR et al., 2004).

A viabilidade da propagação vegetativa tende a aumentar com a aplicação de reguladores vegetais. Dentre eles, há a auxina sintética ácido indolilbutírico (AIB), a qual pode acelerar o processo de indução radicial, aumentando a porcentagem de enraizamento das estacas, número e qualidade das raízes formadas (FACHINELLO et al., 1994; ONO; RODRIGUES, 1996; ZUFFELLATO-RIBAS; RODRIGUES, 2001).

O aprimoramento dessa técnica promove uma contribuição significativa para ampliação da base silvicultural de espécies nativas com fins econômicos, recuperação de áreas e ecossistemas degradados. Assim, o presente trabalho objetivou avaliar diferentes métodos de indução de brotações epicórmicas (decepa e envergadura de caule de plantas matrizes) e a aplicação de AIB no enraizamento adventício de estacas semilenhosas de Vochysia bifalcata.

\section{MATERIAIS E MÉTODOS}

\section{Estaquia}

Para a realização do experimento foram utilizadas brotações epicórmicas induzidas por meio de decepa e envergadura de caule de plantas matrizes de Vochysia bifalcata, coletadas na Reserva Natural do Rio Cachoeira, pertencente à Sociedade de Pesquisa em Vida Selvagem e Educação Ambiental (SPVS), no município de Antonina - PR, sob as coordenadas $25^{\circ} 19^{\prime} 15^{\prime}$ 'S e $45^{\circ} 42^{\prime} 24^{\prime \prime}$ W. Segundo a classificação de Köppen, o clima da região é do tipo $\mathrm{Cfa}$, isto é, clima caracterizado como subtropical com temperatura média do mês mais frio inferior a $18^{\circ} \mathrm{C}$ (mesotérmico) e temperatura média do mês mais quente acima de $22^{\circ} \mathrm{C}$, com verões quentes, geadas pouco frequentes e tendência de concentração de chuvas nos meses de verão, contudo, sem estação seca definida.

As plantas matrizes que foram decepadas apresentavam diâmetro a altura do peito (DAP) de 5 a $7 \mathrm{~cm}$, no qual foi realizado o corte da parte aérea a aproximadamente 1,5 m do solo (Figura 1). A poda foi realizada em cinco plantas matrizes no mês de março de 2010 e em mais seis plantas matrizes, em setembro de 2010.

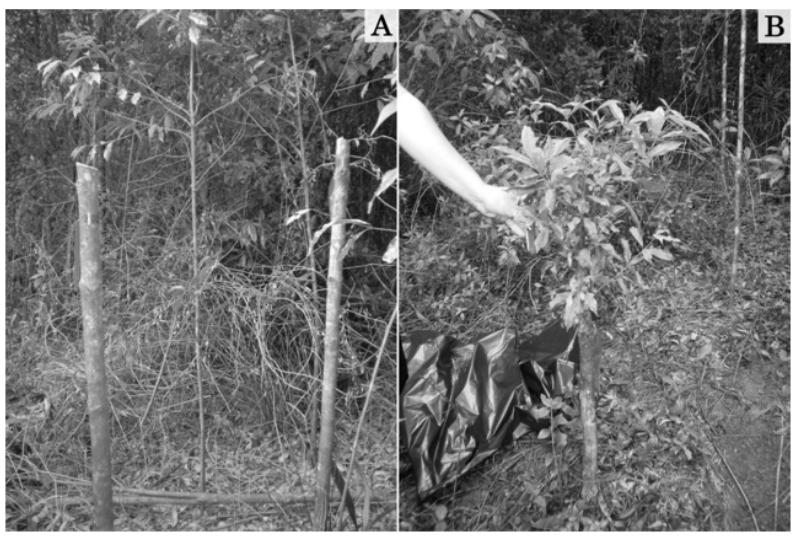

FIGURA 1: A) Decepa de plantas matrizes de Vochysia bifalcata a altura de $1,5 \mathrm{~m}$ do solo; B) Brotações epicórmicas de Vochysia bifalcata oriundas de decepa, coletadas em fevereiro de 2011, entre 5 e 7 meses após o início do crescimento das brotações.

FIGURE 1: A) Stumps of stems of Vochysia bifalcata at a height of $1.5 \mathrm{~m}$ above the ground; B) Epicormic sprouts from stumps of Vochysia bifalcata, collected in February 2011, between 5 and 7 months after the beginning of sprout growth.

Em setembro de 2010, foi realizada a envergadura do caule de outras quatro plantas matrizes, com DAP de 3 a $5 \mathrm{~cm}$ (Figura 2) com o objetivo de promover novas brotações por meio da perda de dominância apical. O processo de envergadura consistiu em curvar o caule em direção ao solo, sem ocasionar quebra do mesmo, sendo o ápice da árvore amarrado, com auxílio de um barbante, a outras plantas que se encontravam próximas.

As brotações epicórmicas emitidas pelas plantas matrizes foram coletadas no dia 14/02/2011, quando atingiram aproximadamente $30 \mathrm{~cm}$ de comprimento, sendo separadas de acordo com a origem da brotação (de decepa e de envergadura de caule). Para aquelas de decepa foi realizada coleta das brotações das duas épocas de poda, para garantir um número mínimo de propágulos para confecção das estacas. A idade das brotações de decepa era de aproximadamente 5 a 7 meses e as de envergadura de caule, aproximadamente 5 meses.

A coleta foi realizada nas primeiras horas da manhã para evitar a desidratação das brotações. 


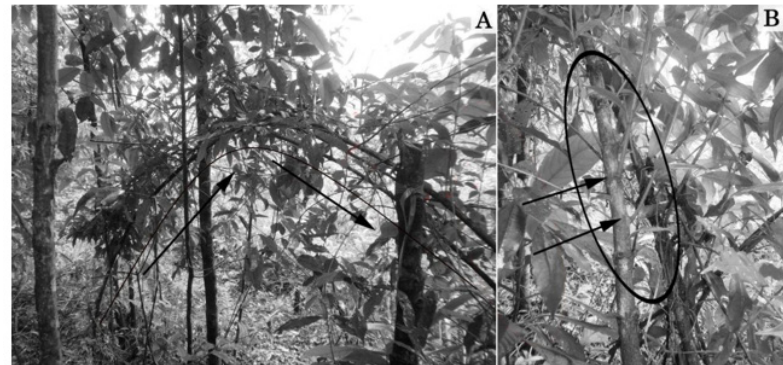

FIGURA 2: A) Envergadura do caule de Vochysia bifalcata. B) Brotações epicórmicas de Vochysia bifalcata oriundas de envergadura de caule, coletadas em fevereiro de 2011, 5 meses após o início do crescimento das brotações epicórmicas.

FIGURE 2: A) Bend of stem of Vochysia bifalcata. B) Epicormic sprouts of Vochysia bifalcata from the bend of stem, collected in February 2011, 5 months after the beginning of epicormic sprouts growth.

Imediatamente após a coleta, foram transportadas até a Embrapa Florestas, em Colombo - PR, em caixas de isopor separadas para cada tipo de brotação epicórmica, contendo uma camada de gelo no fundo e, sobre esta, uma camada de jornal umedecido sobre a qual as brotações foram depositadas. Sobre as brotações foi acrescentada mais uma camada de jornal umedecido para manter a hidratação do material.

Foram confeccionados dois tipos de estacas semilenhosas, de acordo com a origem do material utilizado: a) estacas de brotações de decepa e b) estacas de brotações de envergadura de caule. Para ambos os tipos de estacas, sua confecção foi realizada com 6 a $8 \mathrm{~cm}$ de comprimento, com corte em bisel na base e corte reto na porção superior, mantendo três folhas reduzidas à metade no terço superior da estaca. Durante o processo de confecção, as estacas foram mantidas em balde com água para evitar a desidratação do material.

Posteriormente, as bases das estacas foram imersas em solução hidroalcoólica a 50\% (água destilada:etanol 96\%) de ácido indolilbutírico (AIB) por 10 segundos, nos seguintes tratamentos: $0 \mathrm{mg}$ $\mathrm{L}^{-1} \mathrm{AIB}$ (T1 - testemunha) e $1000 \mathrm{mg} \mathrm{L}^{-1}$ AIB (T2). No tratamento $\mathrm{T} 1$ ( $\left.0 \mathrm{mg} \mathrm{L}^{-1} \mathrm{AIB}\right)$, a base das estacas foi imersa em solução de água destilada e etanol $96 \%(50 \% \mathrm{v} / \mathrm{v})$, sem adição de regulador vegetal. O ácido indolilbutírico P.A. utilizado foi proveniente do Laboratório Merck.

As estacas foram plantadas em tubetes de polipropileno com capacidade de $53 \mathrm{~cm}^{3}$, preenchidos com vermiculita de granulometria média e casca de arroz carbonizada $(1: 1 \mathrm{em} \mathrm{v} / \mathrm{v})$, por cerca de $2 \mathrm{~cm}$ de profundidade e acondicionadas em casa de vegetação climatizada com nebulização intermitente (temperatura de $24^{\circ} \mathrm{C} \pm 2^{\circ} \mathrm{C}$ e superior a $80 \%$ de umidade relativa do ar), pertencente à Embrapa Florestas, em Colombo - PR.

Transcorridos 60 dias após a instalação dos experimentos foram avaliadas as variáveis porcentagem de enraizamento (estacas vivas que apresentavam raízes de, pelo menos, $2 \mathrm{~mm}$ de comprimento); número de raízes por estaca; comprimento das três maiores raízes por estaca (cm); porcentagem de estacas com calos (estacas vivas, sem raízes, com formação de massa celular indiferenciada na base); porcentagem de estacas vivas (estacas vivas que não apresentaram indução radicial nem formação de calos); porcentagem de estacas mortas (estacas que se encontravam com tecidos necrosados).

Os experimentos foram implantados segundo delineamento inteiramente casualizado em esquema fatorial $2 \times 2$ (duas origens de estacas $\mathrm{x}$ duas concentrações de AIB), com quatro repetições de 15 estacas por unidade experimental, totalizando 240 estacas.

As variâncias dos tratamentos foram testadas quanto à homogeneidade pelo teste Bartlett. As variáveis que apresentaram diferenças significativas pelo teste $\mathrm{F}$ tiveram, quando necessário, suas médias comparadas pelo teste Tukey, em nível de $5 \%$ de probabilidade de erro.

\section{Análises anatômicas}

Juntamente com a instalação do experimento de enraizamento, realizado em fevereiro de 2011, foram coletadas amostras da base de cinco estacas de cada tipo (proveniente de decepa e de envergadura de caule) de Vochysia bifalcata, com aproximadamente $2 \mathrm{~cm}$ de comprimento, para realização da análise e descrição anatômica, as quais foram fixadas em FAA 70 (formaldeído/ácido acético/etanol 70\% 1:1:18) (JOHANSEN, 1940), por $24 \mathrm{~h}$ e preservadas em etanol $70 \%$ até o início do procedimento de confecção das lâminas vegetais, realizado no Laboratório de Anatomia Vegetal, pertencente a UFPR, Curitiba - PR. 
As lâminas semipermanentes foram confeccionadas a partir dos materiais fixados em FAA 70, preservados em etanol 70\%, emblocados em polietileno (polietilenoglicol 1500), seccionados em micrótomo rotatório (marca Olympus CUT 4055 ) com cortes de $20 \mu \mathrm{m}$ de espessura. Os cortes foram corados com lugol e Sudam III e safrablau (azul de alcian/safranina 9:1) (KRAUS; ARDUIN, 1997). As amostras foram observadas e fotografadas com fotomicroscópio Zeiss com câmera digital Sony Cyber-shot P72 acoplada.

\section{RESULTADOS E DISCUSSÃO}

\section{Estaquia}

A análise de variância revelou que, para as variáveis analisadas, não houve interação entre a origem das estacas e concentração de AIB utilizada, indicando que os fatores são independentes. Somente o fator origem das estacas mostrou diferença significativa. Para a variável porcentagem de estacas com calos não foi realizada análise de variância devido à presença de valores nulos em todos os tratamentos.

As estacas de brotações epicórmicas provenientes de decepa apresentaram maior porcentagem de enraizamento ( $81 \%$ ), assim como maior número de raízes por estaca $(8,0$ raízes/ estaca) e maior comprimento médio das três maiores raízes por estaca $(2,0 \mathrm{~cm})$ quando comparadas àquelas provenientes de envergadura de caule ( $31 \%$ de enraizamento; 3,3 raízes/estaca e $0,7 \mathrm{~cm}$; respectivamente), diferindo significativamente entre si. Isso indica que a decepa foi mais eficiente na indução de brotações de Vochysia bifalcata, as quais promoveram um maior enraizamento, ocorrendo a formação de um sistema radicial mais vigoroso. Uma melhor resposta para estas variáveis indica que as mudas posteriormente formadas possuirão um melhor desenvolvimento, uma vez que mudas com melhor sistema radicial terão maiores chances de sobrevivência quando transplantadas para vaso ou campo (REIS et al., 2000).

A elevada resposta de enraizamento em material proveniente da decepa de caule pode ser explicada pela indução de brotações laterais vigorosas estimuladas pela alteração no balanço hormonal ocasionada pela perda da copa. Com isso, desencadeou-se um sistema de sobrevivência da planta com desvio da maior parte da energia existente para a produção de novos brotos, a fim de recompor a área foliar perdida, na qual possivelmente as novas brotações apresentavam maiores níveis de auxinas, cofatores do enraizamento e carboidratos, e menores níveis de inibidores.

Também se pode considerar que a melhor resposta ao enraizamento de brotações oriundas de decepa em relação às de envergadura de caule pode ser devido ao fato de que os brotos provenientes das gemas laterais da base das plantas possuem maior juvenilidade dos tecidos e são mais vigorosos, fatores que melhoram a capacidade de enraizamento dos mesmos (HARTMANN et al., 2011). Em espécies lenhosas, brotações mais próximas do meristema apical apresentam menor juvenilidade (HACKETT, 1987) e, consequentemente, menor potencial de enraizamento (HACKETT, 1987, ELDRIDGE et al., 1994). Assim, pode-se inferir que as brotações oriundas da envergadura do caule foram originadas de gemas, em geral, mais distantes da base da planta e mais próximas do meristema apical.

Resultados semelhantes sobre o sucesso do enraizamento adventício por meio do rejuvenescimento por decepa de plantas matrizes podem ser evidenciados em outras espécies de difícil enraizamento. Para o gênero Vochysia, podese citar a propagação de Vochysia guatemalensis Donn. Smith, na qual brotações de decepa de plantas matrizes proporcionaram um enraizamento médio de 64\% das estacas (DICK et al., 1998). Para a propagação vegetativa de erva-mate (Ilex paraguariensis St. Hill), também se constatou que brotações de decepa otimizaram o enraizamento das estacas oriundas de plantas matrizes de cerca de 17 anos, chegando à média de $66 \%$ de enraizamento (BITENCOURT et al., 2009).

As estacas provenientes de envergadura de caule apresentaram maior porcentagem de estacas vivas, com média de $29 \%$, e maior percentual de estacas mortas, com média de 39\%, quando comparadas àquelas provenientes de decepa $(2 \%$ e $17 \%$, respectivamente). Isso demonstra que, possivelmente, aquelas de envergadura de caule apresentam baixo grau de juvenilidade comparada às de decepa. Entretanto, esses resultados ainda são considerados positivos, em relação à utilização de estacas de brotação do ano de Vochysia bifalcata, em estudos anteriores com a espécie, a mortalidade foi de $81 \%$, com ausência de estacas enraizadas (DANNER et al., 2010), enquanto que, para o presente experimento, a maior mortalidade foi de $39 \%$.

O tratamento com AIB não incrementou a 
indução radicial, nem contribuiu para o aumento do número de raízes por estaca e comprimento das três maiores raízes por estaca, independente da origem da estaca utilizada. Desta forma, temse a indicação de que a espécie Vochysia bifalcata, apresenta aptidão natural ao enraizamento de estacas coletadas de plantas decepadas, não justificando a aplicação de reguladores vegetais para a indução de raízes adventícias, provavelmente pela quantidade de auxina endógena suficiente para a formação de raízes.

Resultados semelhantes foram obtidos em experimento com erva-mate (Ilex paraguariensis St. Hill), no qual estacas provenientes de decepa não necessitaram da aplicação de AIB para promover o enraizamento adventício (BITENCOURT et al., 2009), assim como miniestacas de Piptocarpha angustifolia Mart. ex Reissek e miniestacas de Sapium glandulatum (Vell.) Pax. apresentaram altos percentuais de enraizamento sem a aplicação de regulador vegetal (FERREIRA et al., 2010; FERRIANI et al., 2011). Esses resultados semelhantes se devem à concentração endógena de auxina adequada para o enraizamento em estacas juvenis (HARTMANN et al., 2011).

\section{Análises anatômicas}

Analisando as secções transversais das bases das estacas de brotações epicórmicas de Vochysia bifalcata (Figura 3), observa-se que, tanto para aquelas oriundas de decepa, quanto para envergadura de caule, as estacas caulinares apresentaram epiderme unisseriada, com superfície externa da parede periclinal revestida pela cutícula, identificada pelo teste com Sudam III. A região cortical foi composta de aproximadamente quatro camadas de células colenquimáticas, seguidas de seis camadas de células parenquimáticas para as estacas provenientes de decepa, enquanto que para as estacas de envergadura de caule, essa foi formada por 11 camadas de células.

A diferença anatômica mais evidente entre os dois tipos de estacas foi a de que aquelas de decepa apresentaram um anel descontínuo de fibras perivasculares gelatinosas por toda a extensão cortical do caule, com presença de poucas fibras lignificadas (Figura $3-\mathrm{C}$ ) adjacentes ao floema secundário, características essas que não foram notadas nas estacas de envergadura de caule. O enraizamento adventício de estacas de decepa não foi prejudicado pela presença de fibras as quais foram descontínuas e gelatinosas, não constituindo uma barreira anatômica na formação do sistema radicial, fato esse evidenciado pelos altos percentuais de enraizamento. Observação semelhante foi registrada em Odontonema strictum Kuntze que, ao analisarem a anatomia da base das estacas, verificaram a presença de fibras descontínuas na região cortical não prejudicaram o enraizamento, o qual apresentou alto percentual (ZUFFELLATORIBAS et al., 2005).

O caule de ambos os tipos de estacas encontrava-se em crescimento secundário, com floema secundário, câmbio e xilema secundário. A medula foi parenquimática, contendo ductos de mucilagem e floema incluso.

Por meio do teste histoquímico com lugol foi possível observar a presença de grãos de amido (Figura 4) nas células colenquimáticas e parenquimáticas da região cortical, e também o armazenamento desses grãos nas células parenquimáticas da medula de ambos os tipos de estaca. Apesar das estacas de envergadura de caule terem apresentado elevada concentração de amido, pré-requisito no fornecimento de energia por sua quebra em carboidratos, consumidos no processo de respiração celular, visando à divisão, alongamento e diferenciação dos tecidos, houve um baixo enraizamento desse tipo de estaca, indicando que pode haver outros fatores relacionados, como presença de inibidores.

Pela estrutura anatômica dos dois tipos de estacas de brotações epicórmicas de Vochysia bifalcata, pode-se verificar que aquelas provenientes de envergadura de caule apresentaram menor quantidade de tecido secundário formado. Essa característica evidencia um câmbio menos ativo, o que leva a supor que a menor atividade tenha influenciado em um menor enraizamento. Fato semelhante foi notado em estacas de Vitis rotundifolia cv. "Topsail", verificando-se uma baixa atividade do câmbio coincidindo com menores percentuais de enraizamento com relação às demais cultivares estudadas (MAYER et al., 2006).

\section{CONCLUSÕES}

Para a propagação vegetativa de Vochysia bifalcata, o uso de brotações epicórmicas induzidas por decepa de caule proporciona melhor enraizamento adventício do que de envergadura de caule, não necessitando da aplicação de ácido indolilbutírico (AIB). 

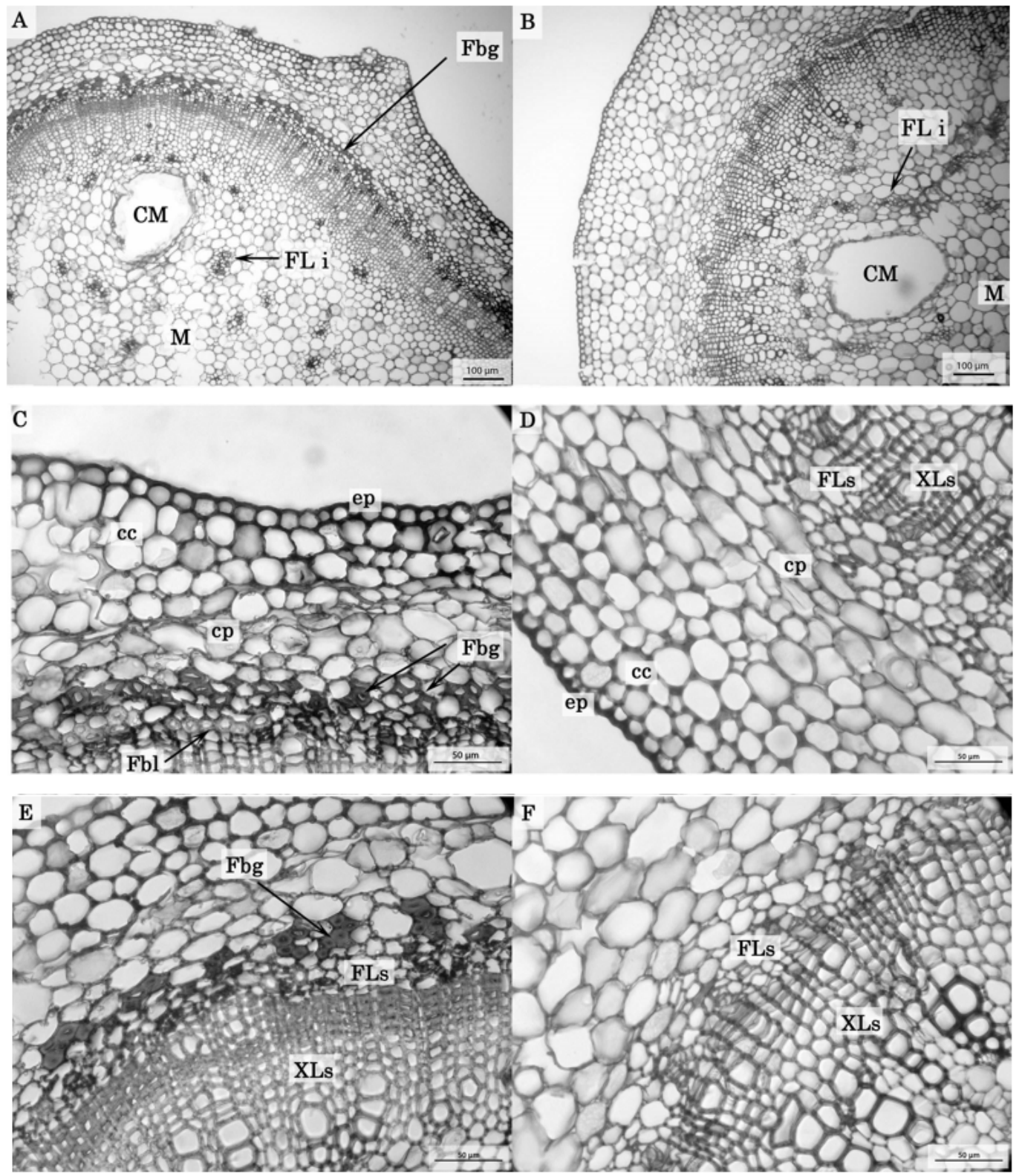

FIGURA 3: Secções transversais da base das estacas de brotações epicórmicas de Vochysia bifalcata. $(\mathbf{A}, \mathbf{C}, \mathbf{E})$ - Visão geral do caule, detalhe da região cortical e detalhe do tecido vascular de estacas oriundas de decepa. (B, D, F) - Visão geral do caule, detalhe da região cortical e detalhe do tecido vascular de estacas oriundas de envergadura de caule. ep - epiderme; cc - células colenquimáticas; $\mathbf{c p}$ - células parenquimáticas; FBg - fibras gelatinosas; FBl fibras lignificadas; FLs - floema secundário; XLs - xilema secundário; FLi - floema incluso; $\mathbf{C M}$ - canal de mucilagem; $\mathbf{M}$ - medula

FIGURE 3: Cross base sections of Vochysia bifalcata cuttings of epicormic shoots. (A, C, E) - Overview of the stem, details of the cortical region and of the vascular tissue of cuttings derived from stump. (B, D, F) - Overview of the stem, details of the cortical region and of the vascular tissue of cuttings derived from bend of stem. ep - epidermis; cc - collenchyma cells; $\mathbf{c p}$ - parenchyma cells; FBg - gelatinous fibers; FBI - lignified fibers; FLs - secondary phloem; XL - secondary xylem; FLi - included phloem; CM - channel mucilage; $\mathbf{M}$ - marro 


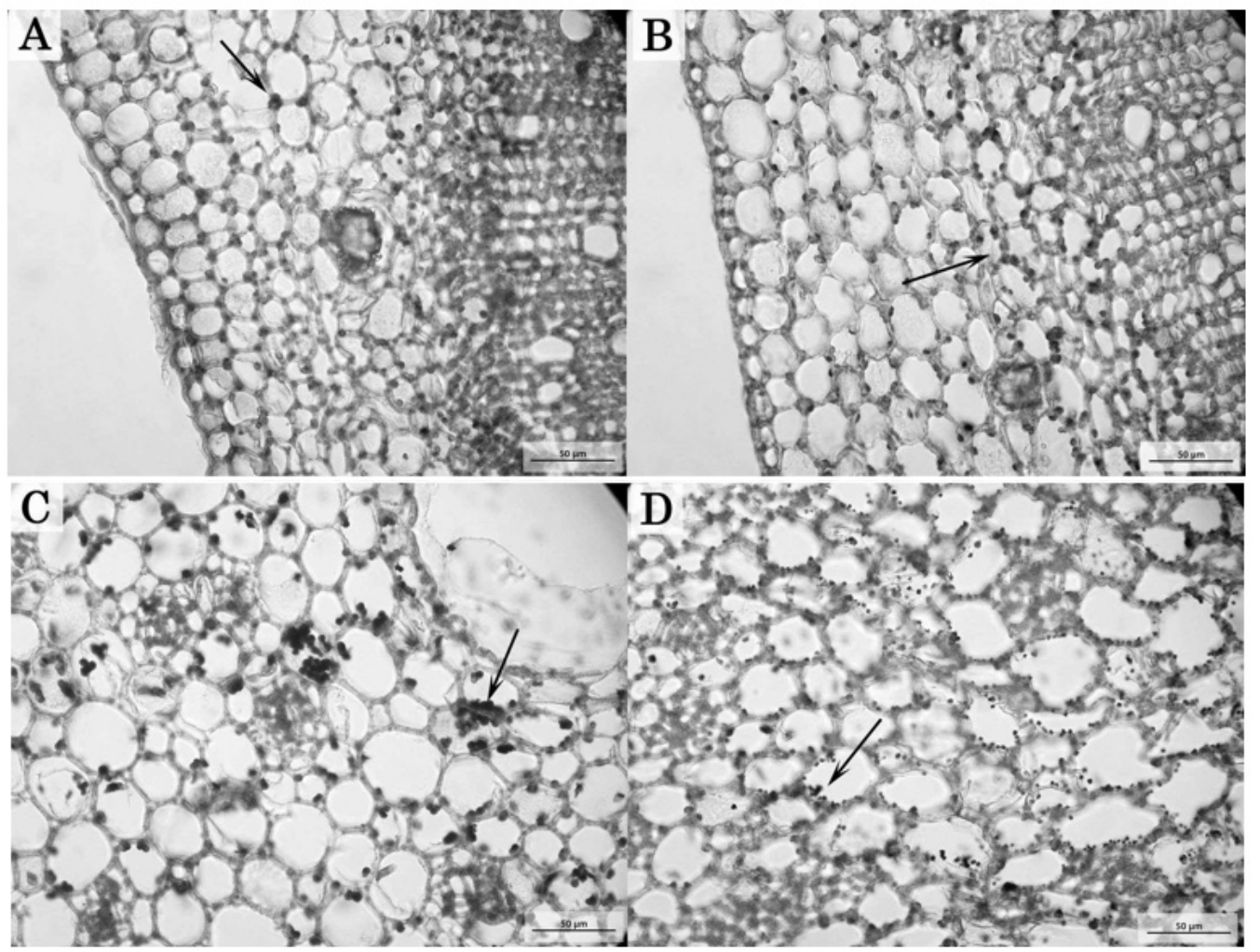

FIGURA 4: Teste de lugol para detecção de amido em secções transversais da base das estacas de Vochysia bifalcata de brotações epicórmicas de região cortical de estacas oriundas de decepa (A) e de envergadura de caule (B). Medula das estacas oriundas de decepa $(\mathbf{C})$ e de envergadura de caule (D)

FIGURE 4: Lugol test to detect starch in cross base sections of Vochysia bifalcata cuttings of epicormic shoots. Cortical region of cuttings derived from stump (A) and from bend of stem (B). Marrow of cuttings derived from stump (C) and from bend of stem (D)

\section{REFERÊNCIAS BIBLIOGRÁFICAS}

BITENCOURT, J. de. Otimização do enraizamento de estacas de plantas adultas de erva-mate. $162 \mathrm{f}$. Tese (Doutorado em Agronomia - Produção Vegetal) - Departamento de Fitotecnia e Fitossanitarismo, Setor de Ciências Agrárias, Universidade Federal do Paraná: Curitiba, 2009.

BITENCOURT, J. et al. Enraizamento de estacas de erva-mate (Ilex paraguariensis A. St.-Hill.) provenientes de brotações rejuvenescidas. Revista Brasileira de Plantas Medicinais, Botucatu, v. 11, n. 3, p. 277-281, 2009.

BORGES JÚNIOR, N. et al. Rebrota de cepas de árvores adultas de acácia-negra (Acacia mearnsii De Wild.). Revista Árvore, Viçosa, v. 28, n. 4, p. 611-615, 2004.

CARPANEZZI, A. A.; CARPANEZZI, O. T. B. Espécies nativas recomendadas para a recuperação ambiental no Estado do Paraná, em solos não degradados. Colombo: Embrapa Florestas, 2006. 54 p. Disponível em: <http://www. cnpf.embrapa.br/publica/seriedoc/edicoes/doc136. pdf $>$. Acesso em: 29 set. 2009. (Documentos, 136). CARVALHO, P. E. R. Guaricica (Vochysia bifalcata). Colombo: Embrapa Florestas, 2008. 6 p. Disponível em: <http://www.cnpf.embrapa.br/ publica/circtec/edicoes/circ-tec150.pdf $>$. Acesso em: 27 set. 2009. (Circular Técnica, 150).

DANNER, M. A. et al. Estaquia semilenhosa de Vochysia bifalcata. Scientia Agraria, Curitiba, v. 11, n. 6, p. 487-491, 2010.

DICK, J. McP. et al. Genetic variation in the number of cuttings harvestable and rooted from Vochysia guatemalensis coppiced stumps. Forest Ecology and Management, v. 111, n. 2-3, p. 225-230, 1998. ELDRIDGE K. et al. Eucalypt domestication and breeding. Oxford: Clarendon Press, 1994. 
p. 228-246.

FACHINELlO, J. C.et al. Propagação de Plantas Frutíferas de Clima Temperado. Pelotas: UFPel, 1994. $179 \mathrm{p}$.

FERREIRA, B. G. A. et al. Miniestaquia de Sapium glandulatum (Vel.) Pax com o uso de ácido indol butírico e ácido naftaleno acético. Ciência Florestal, Santa Maria, v. 20, n. 1, p. 19-31, 2010.

FERRIANI, A. P. et al. Produção de brotações e enraizamento de miniestacas de Piptocarpha angustifolia. Pesquisa Florestal Brasileira, Colombo, v. 31, n. 67, p. 257-264, 2011.

FERRIANI, A. P.; ZUFFELLATO-RIBAS, K. C.; WENDLING, I. Miniestaquia aplicada a espécies florestais. Revista Agro@mbiente on line, Boa Vista, v. 4, n. 2, p. 102-109, 2010.

HACKETT, W. P. Donor plant maturation and adventitious root formation. In: DAVIES, $\mathrm{T}$. D.; HAISSIG, B. E.; SANKHLA, N. (eds.) Adventitious root formation in cuttings. Portland: Dioscorides Press, 1987. p. 11 - 28. (Advances in Plant Sciences Series, 2).

HARTMANN, H. T. et al. Hartmann and Kerster's PLANT PROPAGATION: principles and practices. 8th ed. Boston: Prentice Hall. 2011. $915 \mathrm{p}$.

JOHANSEN, D. A. Plant Microtechnique. New York: McGraw-Hill, 1940. 523 p.

KRAUS, J. E.; ARDUIN, M. Manual básico de métodos em morfologia vegetal. Seropédica: EDUR, 1997. 198 p.

LORENZI, H. Árvores brasileiras: manual de identificação e cultivo de plantas arbóreas nativas do Brasil. Nova Odessa: Instituto Plantarum, v. 2, 1998. p. 352
MAYER, J. L. S.; BIASI, L. A.; BONA, C. Capacidade de enraizamento de estacas de quatro cultivares de Vitis L. (Vitaceae) relacionada com os aspectos anatômicos. Acta Botânica Brasílica, Feira de Santana, v. 20, n. 3, p. 563-568, 2006.

NEGRELLE, R. R. B.; MOROKAWA, R.; RIBAS, C. P. Vochysia Aubl. do Estado do Paraná, Brasil. Acta Scientiarum. Biological Sciences, Maringá, v. 29, n. 1, p. 29-38, 2007.

ONO, E. O.; RODRIGUES, J. D. Aspectos da fisiologia do enraizamento de estacas caulinares. Jaboticabal: FUNEP, 1996. 83 p.

REIS, J. M. R. et al. Efeito do estiolamento e do ácido indolbutírico no enraizamento de estacas de porta-enxerto Pyrus calleryana Dcne. Ciência e Agrotecnologia, Lavras, v. 24, n. 4, p. 931-938, 2000.

SEITZ, R. A. Manual de Poda de Espécies Arbóreas Florestais. Disponível em: $<\mathrm{http}: / /$ www. ipef.br/publicacoes/curso_arborizacao_urbana/ cap08.pdf $>$. Acesso em: 20 Nov 2011.

TAIZ, L. ZEIGER, E. Fisiologia Vegetal. 4. ed. Porto Alegre: Artmed, 2009. 848 p.

WENDLING, I.; XAVIER, A. Gradiente de maturação e rejuvenescimento aplicado em espécies florestais. Floresta eAmbiente, Seropédica, v. 8, n. 1, p. 187-194, 2001.

ZUFFELLATO-RIBAS, K. C. et al. Enraizamento e morfo-anatomia de estacas caulinares de Odontonema strictum Kuntze (Acanthaceae). Revista Brasileira de Horticultura Ornamental, Campinas, v. 11, n. 1, p. 57-61, 2005.

ZUFFELLATO-RIBAS, K. C.; RODRIGUES, J. D. Estaquia: uma abordagem dos principais aspectos fisiológicos. Curitiba: [K. C. Zuffellato-Ribas], 2001.39 p. 